DOI $10.52727 / 2078-256 X-2021-17-3-9-9$

\title{
ОСОБЕННОСТИ ВЗАИМОСВЯЗИ УРОВНЯ СВОБОДНЫХ ЖИРНЫХ КИСЛОТ С ПАРАМЕТРАМИ МЕХАНИКИ ЛЕВОГО ЖЕЛУДОЧКА У БОЛЬНЫХ С ЭПИКАРДИАЛЬНЫМ ОЖИРЕНИЕМ
}

\author{
О.В. Гриценко ${ }^{1}$, Г.А. Чумакова ${ }^{2,3}$ \\ ${ }^{1}$ КГБУЗ «Алтайский краевой кардиологический диспансер», Барнаул, Россия \\ ${ }^{2}$ ФГБУ «Научно-исследовательский институт комплексных проблем сердечно-сосудистых заболеваний», \\ Кемерово, Россия \\ ${ }^{3}$ ГБОУ ВПО «Алтайский государственный медицинский университет» Минздрава России, \\ Барнаул, Россия
}

В настоящее время предложен термин «липотоксичность миокарда», отражающий неблагоприятную статистику кардиологической заболеваемости и смертности при висцеральном ожирении. При таком липотоксическом нарушении происходит повышенное потребление кардиомиоцитами свободных жирных кислот (СЖК), в результате чего запускается каскад апоптоза, что в конечном счете приводит к формированию фиброза миокарда, который, как известно, является патофизиологической основой диастолической дисфункции (ДД) левого желудочка (ЛЖ). Speckle-tracking визуализация может быть использована для диагностики ДД, вызванной липотоксическим поражением миокарда, на доклинической стадии.

Цель. изучить особенности взаимосвязи уровня свободных жирных кислот с параметрами механики левого желудочка у больных с эпикардиальным ожирением (ЭО).

Материал и методы. В исследование было включено 125 мужчин с общим ожирением. Всем пациентам проводилась трансторакальная эхокардиография (ЭхоКГ) с целью оценки толщины эпикардиальной жировой ткани (тЭЖТ) как эквивалента висцерального ожирения, а также для диагностики диастолической дисфункции (ДД) левого желудочка (ЛЖ). По результатам ЭхоКГ пациенты были разделены на две группы: ЭО (+) с толщиной эпикардиального жира (тЭЖТ) $\geq 7$ мм $(n=78)$; ЭО $(-)$ с тЭЖТ <7 мм $(n=40)$. Всем пациентам определялся уровень СЖК в крови с использованием иммуноферментного анализа. С помощью speckle-tracking ЭхоКГ изучена механика ЛЖ (скручивание ЛЖ, скорость скручивания ЛЖ, время до пика скручивания ЛЖ, скорость рас- кручивания ЛЖ, время до пика раскручивания ЛЖ). Критериями исключения было наличие коронарной патологии, артериальной гипертензии, сахарного диабета 2 типа, как возможной причины фиброза миокарда. Также критерием исключения было наличие ДД ЛЖ, выявленной при проведении трансторакальной ЭхоКГ. ДД ЛЖ была выявлена у семи пациентов, которые в последующем были исключены из анализа.

Результаты. В группе пациентов с ЭО (+) выявлено статистически значимое повышение уровня СЖК - 0,82 $(0,39 ; 1,30)$ ммоль/л, а в группе ЭО (-) - 0,36 $(0,19 ; 0,51)$ ммоль/л, $p<0,0001$. С целью оценки влияния тЭЖТ на возникновение липотоксического поражения проведен однофакторный регрессионный анализ. По результатам данного анализа выявлено, что тЭЖТ оказывает статистически значимое влияние $(F=7,90 ; p=0,006)$ на уровень СЖК. По результатам speckle-tracking ЭхоКГ в группе ЭО (+) определялось повышение скорости раскручивания ЛЖ до $-125,56(-141,0$; $-117,0)$ град $/ \mathrm{c}^{-1}(p=0,003)$ и увеличение времени до пика раскручивания ЛЖ 469,44 (509,0; $401,0)$ мс в сравнении с группой ЭО (-) $(p=0,03)$. При проведении корреляционного анализа между параметрами механики ЛЖ и изучаемыми маркерами липотоксического поражения (СЖК) выявлена статистически значимая взаимосвязь между скоростью раскручивания ЛЖ и СЖК $(r=0,24 ; p=0,04)$.

Заключение. Повышение уровня СЖК при ЭО без выявленной ДД ЛЖ при помощи традиционных показателей ЭхоКГ, тогда как выявлена связь с раскручиванием ЛЖ с помощью speckle-tracking ЭхоКГ, может служить маркером раннего липотоксического поражения миокарда. 